\title{
Feline Infectious Peritonitis
}

\author{
Raoul J. de Groot and Marian C. Horzinek
}

\section{INTRODUCTION}

Feline infectious peritonitis (FIP) is one of the most intriguing diseases caused by a coronavirus. It involves immune-mediated phenomena such as antibodydependent enhancement of virus infection- and immune complex-induced pathology. Furthermore, there is increasing evidence for the existence of a carrier state. FIP and feline coronaviruses have been extensively reviewed (Pedersen, 1976b, 1983a,b, 1987a; Barlough and Stoddart, 1986, 1990; Olsen, 1993). Most of these reviews emphasized the pathology, epidemiology, and classical virology. During the last 10 years, our knowledge of the molecular biology of feline coronaviruses has increased considerably. We will summarize clinicopathological findings and the history of FIP research only briefly. The focus will be on the molecular aspects of feline coronaviruses and of FIP pathogenesis.

\section{CLINICAL SIGNS AND PATHOLOGY}

FIP is a progressive, debilitating lethal disease of domestic and wild Felidae. The disease is characterized by disseminated perivascular pyogranulomatous inflammation and exudative fibrinous serositis in the abdominal and thoracic cavities. The initial signs of naturally occurring FIP are not very characteristic. The affected cats show anorexia, chronic fever, and malaise. Occasionally, ocular and neurological disorders occur. In classical "wet" or effusive FIP these signs are accompanied by a gradual abdominal distension due to the accumulation of a viscous yellow ascitic fluid. The quantity of fluid can vary from a few

RAOUL J. DE GROOT AND MARIAN C. HORZINEK - Virology Division, Department of Infectious Diseases and Immunology, University of Utrecht, 3584 CL Utrecht, The Netherlands.

The Coronaviridae, edited by Stuart G. Siddell, Plenum Press, New York, 1995. 
milliliters to well over a liter. There is also the "dry" or noneffusive form of FIP where little or no exudate is present. The wet and dry forms of FIP are different manifestations of the same infection (Montali and Strandberg, 1972). Gross FIP lesions appear as multiple grayish-white nodules $(<1$ to $10 \mathrm{~mm})$ in the serosal membranes, liver, lungs, spleen, omentum, intestines, and kidneys (Wolfe and Griesemer, 1971; Montali and Strandberg, 1972). Microscopic lesions consist of disseminated foci of necrosis and pyogranulomatous inflammation, frequently located around smaller vessels. These lesions are characterized by accumulations of fibrin and necrotic debris and by perivascular infiltrations of macrophages, neutrophils, and lymphocytes (Wolfe and Griesemer, 1971; Montali and Strandberg, 1972; Hayashi et al., 1977; Weiss et al., 1980).

\section{DISCOVERY AND EARLY STUDIES}

The early 1960s are usually quoted as the period when FIP was first recognized (Holzworth, 1963; Feldmann and Jortner, 1964). However, the disease was probably seen earlier. In 1912/13, a case of conspicuous abdominal distension due to ascites formation in a domestic cat was reported (Jakob, 1914); the retrospective diagnosis is supported by the description of fever, high specific gravity of the abdominal fluid containing many granulocytes, and ophthalmological signs in this animal (Fig. 1).

The infectious nature of FIP was established by Wolfe and Griesemer (1966). These authors showed that FIP could be produced in specific pathogenfree cats by intraperitoneal inoculation of ascitic fluid collected from diseased cats. Zook et al. (1968) and Ward et al. (1968) were the first to present evidence supporting a viral etiology. Filtration studies indicated that the causative agent could pass $200-\mathrm{nm}$ pores. In areas of inflammation, viral particles were observed by electron microscopy within or budding into the endoplasmic reticulum of macrophagelike cells (Zook et al., 1968; Ward et al., 1968; Ward, 1970; Pedersen, 1976a). The viral etiology was formally proven by transmission experiments using virus grown in autoch thonous peritoneal macrophage cultures (Pedersen, 1976a) and virus suspensions purified by density gradient techniques (Horzinek et al., 1977).

The morphology and morphogenesis of FIP virus (FIPV) was typical of a coronavirus (Zook et al., 1968; Ward, 1970). Serological studies revealed an antigenic relationship between FIPV and established members of the Coronaviridae family, such as porcine transmissible gastroenteritis virus (TGEV), canine coronavirus (CCV), and the human coronavirus (HCV) 229E (Reynolds et al., 1977; Witte et al., 1977; Pedersen et al., 1978; Horzinek et al., 1982). In fact, CCV, TGEV, and FIPV are antigenically so similar that they may be regarded as host range mutants rather than as separate species (Horzinek et al., 1982). Consistent with this view, inoculation of FIPV causes TGE-like lesions in the small intestine of piglets (Woods et al., 1981). Furthermore, FIP-like pyogranulomatous lesions were found in cats experimentally infected with the CCV strain Insvac-1 (McArdle et al., 1992). Another coronavirus of pigs, the porcine epidemic diarrhea virus (PEDV), was found to be antigenically related to FIPV; 
FIGURE 1. Probably the earliest case of FIP documented in the literature (at the State Veterinary School in Utrecht, 1912/13); the retrospective diagnosis is plausible from the description of a chronic exudative peritonitis, dyspnea (pleuritis?), fever, and eye symptoms (Jakob, 1914).

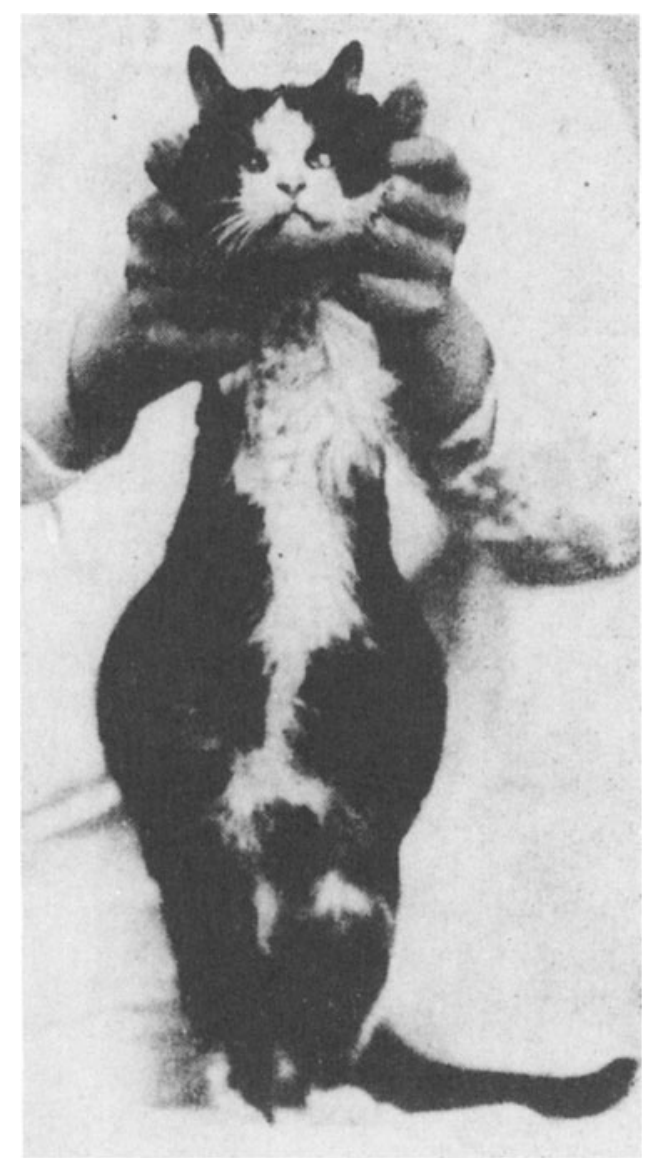

serological cross-reactions were confined to the nucleocapsid protein (Zhou et al., 1988).

The isolation of feline coronaviruses (FCoVs) from naturally infected cats is notoriously difficult, probably due to their poor in vitro growth; FCoV strains isolated so far are listed in Table I. Since initial attempts to grow the virus in embryonated eggs, primary cells, and continuous cell lines were not successful, FCoV strains were adapted to and propagated in the brains of suckling mice, rats, and hamsters (Osterhaus et al., 1978a,b). In vitro propagation was first reported in macrophage cultures (Pedersen, 1976a). A breakthrough was the finding that FCoVs could be grown in continuous lines and primary cultures of feline fetal cells (O'Reilly et al., 1979; Black, 1980; Evermann et al., 1981; Pedersen et al., 1981a). Currently, FCoVs are mostly grown in Crandell feline kidney (CrFK) cells, feline embryonic lung (FEL) cells (O'Reilly et al., 1979), and the line of Felis catus whole fetus (fcwf) cells developed by Niels Pedersen; the latter exhibit macrophagelike features at early passage levels (Jacobse Geels and Horzinek, 1983). 
TABLE I. Feline Coronavirus Isolates

\begin{tabular}{lcl}
\hline Strain & Presumptive serotype & \multicolumn{1}{c}{ Reference } \\
\hline FIPV UCD1 (NW1) & I & Pedersen et al. (1981a) \\
FIPV UCD2 & I & Pedersen and Floyd (1985) \\
FIPV UCD3 & I & Pedersen and Floyd (1985) \\
FIPV UCD4 & I & Pedersen and Floyd (1985) \\
FIPV UCD5 & $?$ & Pedersen (personal communication) \\
FIPV UCD6 & $?$ & Pedersen (personal communication) \\
FECV UCD & I & Pedersen et al. (1981b) \\
FIPV TN-406 & I & Black (1980) \\
FIPV Yayoi & I & Hayashi et al. (1981) \\
FIPV Dahlberg & $?$ & Osterhaus et al. (1978a) \\
FIPV KU-2 & I & Hohdatsu et al. (1991b) \\
FIPV 79-1146 & II & McKeirnan et al. (1981) \\
FIPV NOR15 (DF2) & II & Everman et al. (1981) \\
FECV 79-1683 & II & McKeirnan et al. (1981) \\
FIPV Cornell-1 & II & Scott (1987) \\
FIPV KU-1 & II & Hohdatsu et al. (1991b) \\
FIPV Wellcome & $?$ & O'Reilly et al. (1979) \\
\hline
\end{tabular}

\section{EPIZOOTIOLOGY AND EPIDEMIOLOGY}

Although FIP is a disease mainly of domestic cats, it has been reported in several wild felids, such as the lion (Colby and Low, 1970), leopard (Tuch et al., 1974), European wildcats (Watt et al., 1993), caracal, and lynx (Poelma et al., 1971). The cheetah (Acinonyx jubatus) is extremely sensitive FIP, a peculiarity attributed to the genetic uniformity in this species (O'Brien et al., 1985).

FIP occurs in domestic cats of both sexes at about the same frequency (Pedersen, 1976c). The disease occurs most commonly in young cats between 6 months and 2 years of age. In cats between 5 and 13 years of age, FIP is less prevalent; but there appears to be an increased incidence in cats older than 14 years (Pedersen, 1976c, 1983a,b; Addie and Jarrett, 1992a). Close contact between cats is required for effective transmission. Virus is shed from the oropharynx and in the feces (Stoddart et al., 1988a,b). Therefore, the infection most likely results from ingestion and/or inhalation of the virus.

Epidemiological studies showed that FCoVs have a worldwide distribution (Horzinek and Osterhaus, 1979) and are widespread in the cat population. Antibodies directed against FIPV or a closely related coronavirus are found in 80 to $90 \%$ of the cats in catteries and in 10 to $50 \%$ of the cats in single cat households (Pedersen, 1976c; Loeffler et al., 1978; Sparkes et al., 1991, 1992; Addie and Jarrett, 1992a,b). The disease itself, however, occurs sporadically: only 5 to $10 \%$ of the seropositive cats actually develop FIP (Pedersen, 1976b; Addie and Jarrett, 1992a,b). These findings seem at odds with the fact that certain FIPV strains such as $79-1146$ cause FIP in almost $100 \%$ of the experimentally infected cats. To explain this discrepancy, it was initially proposed that most cats in the field become infected with an avirulent virus closely related to FIPV. The isolation of two strains, UCD (Pedersen et al., 1981b) and 79-1683 
(McKeirnan et al., 1981), that only cause a mild enteric infection but no FIP seemed to support this view. These avirulent viruses were designated feline enteric coronaviruses (FECVs) (Pedersen et al., 1981b, 1984; Pedersen, 1983a). There is now, however, ample evidence that FECV and FIPV are merely virulence variants of the same virus. The FECV isolates are antigenically (Pedersen et al., 1983; Boyle et al., 1984; Fiscus and Teramoto, 1987a; Hohdatsu et al., 1991a,b; W. V. Corapi, personal communication) and genetically (Herrewegh, Horzinek, Rottier, and de Groot, in preparation; see Section VI) indistinguishable from FIPV strains. The antigenic differences between FIPV 79-1146 and FECV 79-1683 (Fiscus et al., 1987; Hohdatsu et al., 1991b) simply reflect FCoV strain variations and do not correlate with their respective pathogenic properties. FECV 79-1683 is antigenically (Pedersen et al., 1984; Hohdatsu et al., 1991a,b; W. V. Corapi, personal communication) and genetically (Herrewegh, Vennema, Horzinek, Rottier, and de Groot, in preparation; see Section VI) more similar to FIPV 79-1146 than to FECV strain UCD. Moreover, attenuated FIPV strains with properties similar to FECV are readily obtained (Pedersen and Black, 1983; Barlough and Stoddart, 1990), and it is now recognized that even FIP-inducing strains vary dramatically in their pathogenicity (Pedersen and Floyd, 1985; Pedersen, 1987b). In the field, highly virulent strains may be as uncommon as completely avirulent strains. It is therefore more appropriate to consider all strains under the general category of FCoV (Barlough and Stoddart, 1990; Addie and Jarrett, 1992b).

The outcome of an FCoV-infection not only depends on the virus strain but also on the infective dose and the route of inoculation (Pedersen et al., 1981a; Pedersen and Floyd, 1985), the age of the host, concurrent viral infections [e.g., with feline leukemia virus (FeLV)] (Hardy and Hurvitz, 1971; Cotter et al., 1975; Pedersen and Floyd, 1985; Pedersen, 1987b), "stress" (Pedersen, 1976b), and, possibly, the genetic predisposition of the host (O'Brien et al., 1985; Addie and Jarrett, 1992a,b). The combined data suggest that FIP is an infrequent manifestation of a common, inapparent infection (Loeffler et al., 1978; Horzinek and Osterhaus, 1979; Pedersen, 1976b; Addie and Jarrett, 1992a,b). From an evolutionary point of view, viruses that cause low morbidity and low mortality have a survival advantage, especially if they can establish persistent infections. There is increasing evidence for the occurrence of asymptomatic carriers of FCoV. Kittens exposed to healthy, FCoV-seropositive cats seroconvert within 2 to 10 weeks (Pedersen et al., 1981b; Addie and Jarrett, 1992a); a number of these kittens subsequently develop FIP. Strong support for the existence of a FCoV carrier state stems from a series of experiments in which FIPV-immune cats were immunosuppressed by superinfection with FeLV. Thus, FIP could be induced in cats that were kept in strict isolation up to 4 months after exposure to FIPV (Pedersen and Floyd, 1985; Pedersen, 1987b). The reverse transcriptionpolymerase chain reaction (RT-PCR) detection of FCoV in the feces and plasma of healthy, seropositive cats (Herrewegh et al., 1995) provides further support for a FCoV carrier state.

The epidemiological findings fit a model in which most FCoVs, though in principle pathogenic, behave as innocent commensals. The host's immune system (presumably the cellular arm) (Pedersen, 1987b) keeps the infection in 
check but is unable to clear the virus completely. Thus, upon natural infection disease would only ensue under exceptional circumstances, i.e., when (1) the host is exposed to a high virus dose, (2) the host is unable to develop a protective immune response, or (3) an immunocompetent host is exposed to factors that compromise its immune system.

\section{MOLECULAR BIOLOGY OF FCoV}

As for most other coronaviruses, $\mathrm{FCoV}$ virions are composed of three main structural protein species: a $45-\mathrm{kDa}$ nucleocapsid protein $\mathrm{N}$, a $25-$ to $30-\mathrm{kDa}$ matrix protein $\mathrm{M}$, and a 180 - to $210-\mathrm{kDa}$ peplomer protein $\mathrm{S}$ (Horzinek et al., 1982; Boyle et al., 1984; de Groot et al., 1987a). Virions of TGEV also contain a small membrane protein (sM) of $10 \mathrm{kDa}$ (Godet et al., 1992). Recent data obtained in our laboratory indicate that $\mathrm{sM}$ is present in FCoV virions as well (Vennema, Godeke, Horzinek, and Rottier, in preparation). Further details on the characteristics of the structural proteins and coronavirus assembly will be presented elsewhere in this volume (Chapters 5-9).

The FCoV genome is a positive-stranded RNA molecule with an estimated length of about $30 \mathrm{~kb}$. Thus far, the FCoV strain best characterized at the molecular level is FIPV 79-1146. Initially, six virus-specific, poly(A)-containing RNAs were found in infected cells, with lengths ranging from 1.4 to more than $20 \mathrm{~kb}$. An identical set of RNAs was found in cells infected with FIPV strain NOR15 (de Groot et al., 1987a). Recently, we have obtained evidence for a seventh virus-specific RNA species (see below).

By in vitro translation, subgenomic RNAs of 3.8 and $2.8 \mathrm{~kb}$ were shown to encode the $M$ and $N$ protein, respectively (de Groot et al., 1987a). Sequence analysis of cDNA clones (de Groot et al., 1987b,c) identified the 9.6-kb RNA species to encode the S protein. Of the FIPV 79-1146 genome, the nucleotide sequence downstream of the polymerase gene has now been completed (de Groot et al., 1987b, 1988; Vennema, de Groot, and Spaan, unpublished results). The gene organization is identical to that of CCV strain Insavc-1 (Horsburgh et al., 1992). In addition to the genes encoding N, M, S, and sM, there are five open reading frames (ORFs) (Fig. 2). The sequence $5^{\prime}$ AACUAAAC $3^{\prime}$ is interspersed between the ORFs; the complementary sequence, 3' GUUUAGUU 5', is thought to function as a promoter for subgenomic RNA synthesis (see Chapter 2).

Interestingly, the sM gene is preceded by the partial promoter sequence 3' GUUUAG 5' (Vennema, de Groot, and Spaan, unpublished results), suggesting that it may be translated from a separate, hitherto undetected RNA species (de Groot et al., 1987a, 1988). Upon separation of FIPV RNAs in 1.5\% agarose gels, a minor 4.0-kb RNA species indeed was found. The identity of this RNA was confirmed by RT-PCR using oligonucleotide primers located in ORF4 and the FIPV leader RNA, followed by sequence analysis (Mijnes and de Groot, unpublished results). The mRNA for $\mathrm{sM}$ is made in very low amounts, and in $1 \%$ agarose gels it is masked by the far more predominant $3.8-\mathrm{kb}$ RNA species. In view of these data it seems appropriate to change the nomenclature of the FIPV 


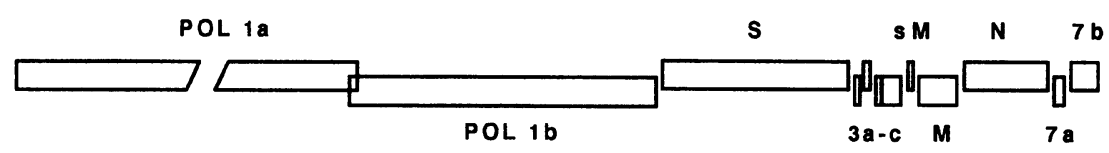

\RNA1

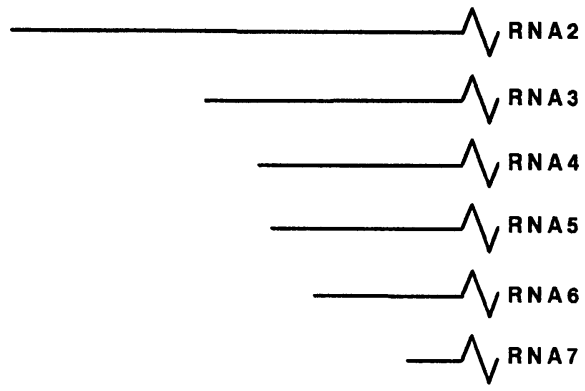

FIGURE 2. Organization and expression of the genome of FIPV strain 79-1146. Open reading frames are indicated by boxes. The structure of the seven FIPV RNAs is also shown.

RNAs as indicated in Fig. 2. The ORFs at the $3^{\prime}$ end of the FIPV genome should thus be referred to as $7 \mathrm{a}$ and $7 \mathrm{~b}$ (formerly $6 \mathrm{a}$ and $6 \mathrm{~b}$ ), according to nomenclature recommended by the Coronavirus Study Group (Cavanagh et al., 1990).

As illustrated in Fig. 2, RNAs 3 and 7 are potentially polycistronic. ORFs $3 a-c$ and ORFs $7 a$ and $7 b$ are thought to encode nonstructural proteins. It is still unclear, however, whether all of these ORFs, in particular ORFs $3 b$ and c, are actually expressed (Horsburgh et al., 1992). The ORF7a homologue of TGEV contains a 69 nucleotide (nt) deletion compared to ORF7a of FCoV and CCV/de Groot et al., 1988; Vennema et al., 1992b; Horsburgh et al., 1992). Its product, a 9.1-kDa hydrophobic protein, has been detected in TGEV-infected cells (Garwes et al., 1989; Tung et al., 1992). It therefore is likely that ORF7a is expressed in FCoV-infected cells as well.

ORF $7 \mathrm{~b}$ is present only in the genomes of FCoV and CCV (Kapke and Brian, 1986; de Groot et al., 1988; Vennema et al., 1992b; see Chapter 3). It codes for a nonvirion secretory glycoprotein, gp $7 \mathrm{~b}$ (Vennema et al., 1992a). The glycoprotein $\mathrm{gp} 7 \mathrm{~b}$ is not required for virus replication in vivo and in vitro: FECV strain 79-1683 contains a large deletion in ORF7b (Vennema et al., 1992b), but replicates to high titers in tissue culture cells and causes enteritis upon experimental infection of cats. Also, ORF7b is readily lost upon in vitro passage of other FCoV strains: large deletions in this gene were found in high passage stocks of strains TN406 and UCD4, in UCD2 and in the DF2-derived Primucell vaccine strain (Herrewegh, Vennema, Horzinek, Rottier, and de Groot, in preparation). Still, with the exception of strain 79-1683, an intact ORF7b is present, at least at low passage numbers, in all nine FCoV laboratory strains studied thus far, including the nonvirulent FECV strain UCD. Moreover, no deletions were found in ORF7b of 16 field strains as determined by RT-PCR analysis on fecal 
samples and tissues (Herrewegh et al., 1995). It therefore appears that although the $7 \mathrm{~b}$ gene is dispensible for replication in tissue culture cells and enterocytes, its presence provides a selective advantage during natural infection.

The function of gp $7 \mathrm{~b}$ remains enigmatic. In the infected cell, the protein is present only in the lumen of the endoplasmic reticulum (ER) and the Golgi (Vennema et al., 1992a). An involvement in cytoplasmic processes such as RNA replication can therefore be excluded. Presumably, gp 7b exerts its function extracellularly, perhaps as a virus-encoded modifier of the immune response and/or inflammatory reaction (Gooding, 1992). The loss of gp7b may well contribute to the reduced virulence of FECV 79-1683, high passage TN406 (Pedersen and Black, 1983), FIPV UCD2, and the Primucell vaccine strain.

\section{SEROLOGICAL AND GENETIC RELATIONSHIPS OF FCoV ISOLATES}

As first noted by Pedersen et al. (1983), FCoVs can be allocated to at least two serotypes on the basis of in vitro neutralization. Sera from cats experimentally infected with so-called type I FCoVs (FIPV TN-406 or FECV UCD) neutralized other type I FCoVs but not type II FCoVs (79-1146 and 79-1683) and vice versa. The type II strains appeared to be more closely related to CCV and TGEV, i.e., immunodominant neutralization epitopes shared by the spike proteins of TGEV, CCV, and the type II FCoV strains seemed to be absent in the type I strains (Pedersen et al., 1983). These findings were confirmed and extended in studies using monoclonal antibodies (MAbs) (Hohdatsu et al., 1991a,b, 1992; W. V. Corapi, personal communication). Strains DF-2 (NOR15), CU1 and KU-1 were tentatively identified as type II viruses, whereas UCD-1, $-2,-3$, and -4 , and Yayoi and KU-2 were assigned to serotype I (Table I) (Hohdatsu et al., 1991a,b; W. V. Corapi, personal communication). Strain UCD-2 is interesting in that a number of epitopes on the spike protein, shared by other group I strains, are absent (Fiscus and Teramoto, 1987a,b; W. V. Corapi, personal communication). This led Fiscus and Teramoto to suggest that UCD-2 represents a separate antigenic type (Fiscus and Teramoto, 1987a).

There is some confusion in regard to the classification of FCoV strain UCD1. According to some reports, UCDl belongs to type I/Pedersen et al., 1983; Hohdatsu et al., 1991a,b). Other studies suggest a closer antigenic relationship to type II strains (Corapi et al., 1992). As it now appears, virus stocks may have been interchanged. The alleged UCD1 strain used by Scotts' group (Corapi et al., 1992; Olsen et al., 1992), is antigenically (W. V. Corapi, personal communication) and genetically more similar to 79-1146 (type II) than to the original type I UCD1 (NW1) strain from Niels Pedersen.

Although the data are limited and rather sketchy, type I FCoV strains seem to predominate in the field. Of 20 sera from natural FIP cases in the United States, only one contained neutralizing antibodies directed against FIPV strain 79-1146 (type II). The remaining 19 antisera neutralized TN-406 (type I) with titers ranging from 40 to 3200 (Pedersen et al., 1983). Hohdatsu et al. (1992) 
screened 237 FCoV-positive sera, as determined by immunofluorescent assay (IFA), by using a neutralization assay with FIPV strain 79-1146 as the test virus and by a competition enzyme-linked immunosorbent assay (ELISA) using a type II-specific MAb. Their results suggest that type II viruses account for only $20-30 \%$ of the natural FCoV infections in Japan.

The type I and II viruses also appear to differ in their in vitro growth characteristics. The type I strains grow poorly in tissue culture, yielding titers of cell-free virus of only 0.5 to $1 \times 10^{5} \mathrm{TCID} 50 / \mathrm{ml}$. More than $90 \%$ of the infectivity remains cell-associated (Pedersen et al., 1983; Pedersen and Floyd, 1985; Hohdatsu et al., 1991b). In contrast, type II FCoVs grow to high titers of cell-free virus (up to $5 \times 10^{7} \mathrm{TCID} 50 / \mathrm{ml}$ ) and also in these properties closely resemble CCV (Pedersen et al., 1983).

One interpretation of the data is that the FCoV are a heterogeneous group, with the type II viruses being genetically more closely related to CCV than to type I strains (Pedersen et al., 1983). The fact that some CCV strains induce FIP upon experimental inoculation of cats (McArdle et al., 1992) would lend further credence to this idea. To study this issue, we compared the $3^{\prime}$-most transcription unit comprising ORFs $7 \mathrm{a}, 7 \mathrm{~b}$, and the $3^{\prime}$ nontranslated sequences (NTR) of nine different FCoV isolates. Nucleotide sequence similarities ranged from 87 to $99 \%$ (Herrewegh, Vennema, Horzinek, Rottier, and de Groot, in preparation). As shown in Fig. 3, types I and II cannot be distinguished in this part of the genome. Clearly, they are much more related to each other than to the CCV strains sequenced thus far.

From serological studies, it appears that the differences between type I and II FCoVs are mostly located in the S-protein (Fiscus and Teramoto, 1987a,b; Hohdatsu et al., 1991a,b; W. V. Corapi, personal communication). Very recently, these findings were confirmed by sequence analysis. The spike genes of type II FCoVs bear much greater resemblance to those of TGEV and CCV than to the spike genes of type I isolates KU-2 (Motokawa et al., 1995) and UCD3 (Vennema et al., 1995). How can these observations be reconciled with those made for the ORF7a/7b transcription unit? During coronavirus replication, homologous RNA recombination occurs at a high frequency. It is quite conceivable that the type II FCoV strains have arisen by RNA recombination between a type I FCoV and CCV (Vennema et al., 1995; Herrewegh et al., in preparation).

Figure 3 also shows that the avirulent "FECV" strains UCD and 79-1683 are more similar to pathogenic "FIPV" strains than to each other. These findings again indicate that the virulent and avirulent FCoVs are not separate virus species.

\section{ANTIBODY-DEPENDENT ENHANCEMENT}

The key pathogenic event in FIP is the infection of monocytes and macrophages (Ward, 1970; Pedersen, 1976a). Avirulent FCoV strains remain confined to the digestive tract and usually do not spread beyond the intestinal epithelium and regional lymph nodes (Pedersen et al., 1981b, 1984). The virulent strains, 


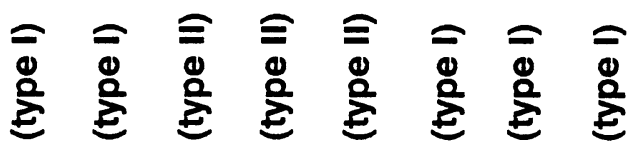

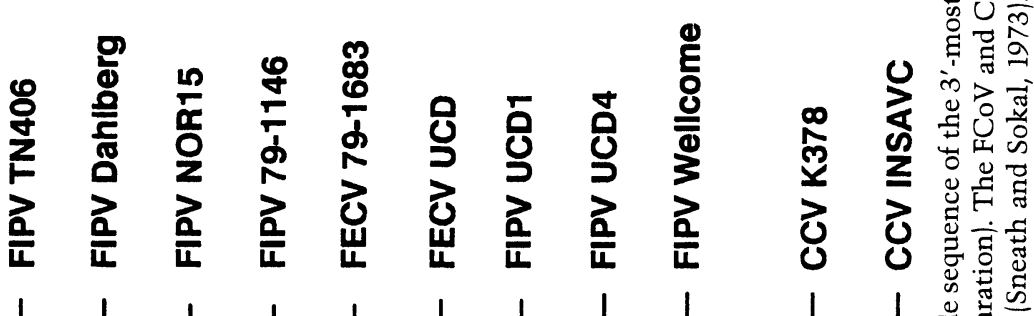

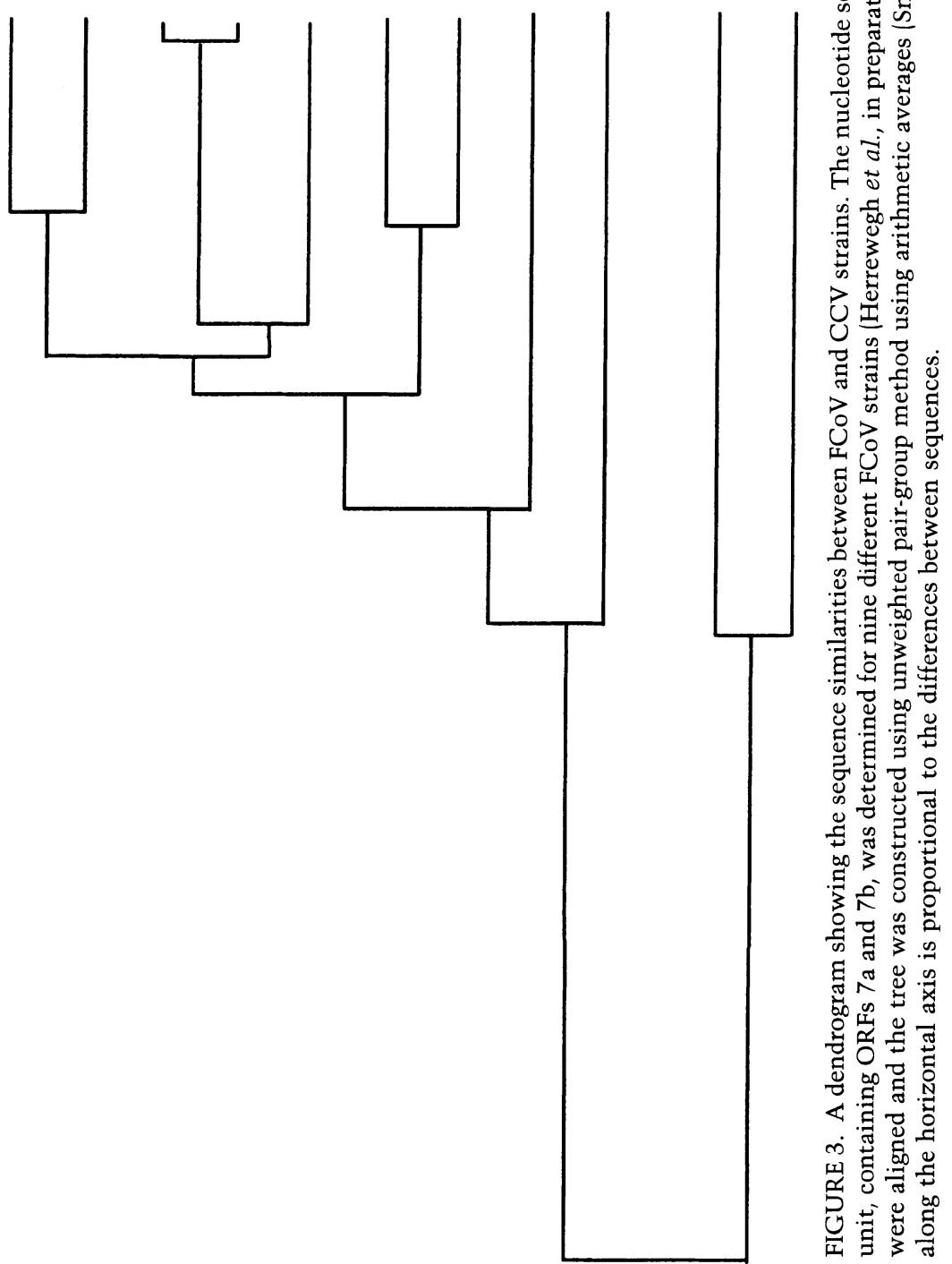

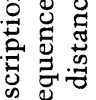

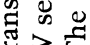
它

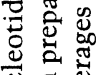
. $g$ की $\forall$ ร 氙 范矛起 $>{ }_{0}^{\infty} \mathbb{E}$ 证高 ग 政 更 \pm 造 政 焉 $\circlearrowleft \Xi$

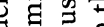
它 का 为 का 3 के 승 응 व 0 त

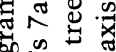
잉 至 임 $\Xi \pi$ 궁 뇜

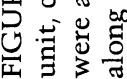


however, disseminate to other organs most likely via blood-borne monocytes (Weiss and Scott, 1981a). The virulence of FCoV strains appears to correlate with their ability to infect feline peritoneal macrophages in vitro. When virulent and avirulent strains were compared, the latter infected fewer macrophages and produced lower virus titers than the virulent strains. Moreover, the avirulent strains were less able to sustain viral replication and to spread to other macrophages (Stoddart and Scott, 1989).

There is ample evidence for an involvement of the immune system in the pathogenesis of FIP. Several authors have emphasized the similarities between FIP and immune-mediated diseases such as Aleutian disease of mink and Dengue hemorrhagic fever (Horzinek and Osterhaus, 1979; Pedersen and Boyle, 1980; Weiss and Scott, 1981b; Halstead, 1988). Humoral immunity is obviously not protective. FCoV-seropositive cats that are experimentally infected with FIPV often develop an accelerated, fulminating course of the disease. Clinical signs and lesions develop earlier, and the mean survival time is dramatically reduced compared to seronegative cats (early death syndrome) (Pedersen and Boyle, 1980; Weiss et al., 1980; Weiss and Scott, 1981a-c). Direct evidence for the involvement of antibodies in early death syndrome was obtained by passive immunization of cats with the purified immunoglobulin IgG fraction of feline $\alpha \mathrm{FCoV}$-antisera. These cats also developed enhanced FIP upon an experimental challenge infection (Pedersen and Boyle, 1980).

Heterologous expression of $S, M$, and $N$ provided a means to assess the role of each individual protein in FIP pathogenesis (de Groot et al., 1989; Vennema et al., 1990b, 1991). S was unequivocally identified as the main, if not the sole, factor in the induction of early death (Vennema et al., 1990b, 1991). Kittens that had been infected with a recombinant vaccinia virus (recVV) expressing $S$ died within 9 days after an FIPV challenge infection. In contrast, kittens that had been infected with wild-type vaccinia virus or with recVVs expressing $M$ or $\mathbf{N}$ either survived FIPV infection or succumbed after a protracted course of the disease (21-41 days) (Vennema et al., 1990b, 1991).

The early death syndrome can be explained by an antibody-dependent enhancement of virus infection (ADE), a phenomenon described for a wide variety of viruses, including the human immunodeficiency virus (Takeda et al., 1988; for reviews, see Porterfield, 1986; Halstead, 1988). Binding of antibody to virus produces infectious immune complexes that attach to the surface of the target cell (via Fc or complement receptors) with higher efficiency than virus alone (Chanas et al., 1982; Burstin et al., 1983; Gollins and Porterfield, 1984, 1985; Halstead and O'Rourke, 1977; Peiris and Porterfield, 1979; Peiris et al., 1981).

Cheryl Stoddart (1989) provided the first in vitro evidence for an involvement of ADE in FIP by using feline peritoneal macrophage cultures (Stoddart and Scott, 1988). The number of macrophages infected with FIPV UCD-1 ${ }^{*}$ in vitro increased up to 12 -fold when the virus had been preincubated with serum from an FIPV-sensitized cat. This enhancement also occurred when using the high-pressure liquid chromatography (HPLC)-purified IgG-fraction of the serum. ADE could be prevented by blocking the macrophage $\mathrm{Fc}$ receptor with aggregated IgG or by blocking the Fc portion of the enhancing IgG with protein 
A (Stoddart, 1989). The levels of enhancement varied greatly between experiments with different batches of macrophages; similar difficulties have been experienced in $\mathrm{ADE}$ studies with peripheral blood leukocyte preparations (Porterfield, 1986).

Recently, these observations were confirmed and extended by Hohdatsu $e t$ al. (1991c) and by Fred Scott's group (Olsen et al., 1992; Corapi et al., 1992). In these studies, ADE in primary feline macrophages was demonstrated both with feline antisera (Olsen et al., 1992; Olsen and Scott, 1993) and with murine monoclonal antibodies (Hohdatsu et al., 1991c; Olsen et al., 1992; Corapi et al., 1992). The variation between experiments was minimized by using batches of macrophages obtained from a single cat (Olsen et al., 1992). Upon screening of 67 MAbs specific for S, M, and N, 17 MAbs were identified that enhanced FIPV infection (Olsen et al., 1992, 1993; Corapi et al., 1992). Consistent with the data of Vennema et al. (1990b, 1991), the ADE-inducing MAbs were all directed against the $S$ protein (Olsen et al., 1992; Corapi et al., 1992). There was a distinct correlation between the ability of the MAbs to neutralize infection of CrFK cells and the induction of ADE: 15 of 19 neutralizing antibodies enhanced FIPV infection. All but one of the enhancing MAbs were of the immunoglobulin G2a subclass; the four neutralizing MAbs that did not induce ADE were of the G1 subclass. From these findings Corapi et al. (1992) suggested a restriction in the immunoglobulin subclasses mediating ADE. The findings of Hohdatsu et al. (1991c) seem to conflict with those of all other authors in that nonneutralizing MAbs directed against both $\mathrm{M}$ and $\mathrm{S}$ induced ADE. However, the enhancement levels obtained with these MAbs were very low (two- to threefold), while in the studies of Olsen et al. (1992) and Corapi et al. (1992) some MAbs produced up to a 100 -fold increase in the number of infected cells. The most convincing enhancement reported by Hohdatsu et al. (1991c) (a sixfold increase in the number of infected cells) notably occurred with a neutralizing S-specific MAb of the immunoglobulin G2a subclass.

There are at least five distinct neutralization sites on the S protein of FIPV, four of which have been implicated in ADE (Corapi et al., 1992). By kineticsbased competitive ELISA, two of the enhancement sites were found to correlate with the previously defined sites A and E/F of the TGEV S protein (Olsen et al., 1992). It was also shown that $\alpha$ TGEV MAbs directed against these sites enhanced FIPV infection in vitro (Olsen et al., 1993). By sequence analysis of MAbresistant mutants and PEPSCAN epitope mapping, amino acid residues involved in the formation of TGEV site $A$ have been localized between amino acid residues 538 and 591 (Correa et al., 1990; Gebauer et al., 1991). The epitopes of the enhancing FIPV site A MAbs are probably located in the homologous region (residues 543-597) (Jacobs et al., 1987) on the FIPV spike (Olsen et al., 1993).

Olsen et al. (1992) noted strain variations of ADE in that certain MAbs would enhance FIPV UCD $-1^{\star}$ more than $79-1146$ and vice versa. This is most likely related to the epitopes recognized by the enhancing MAbs and their relative avidity. These observations may in part explain why FIPV does not always cause antibody-mediated early death in seropositive cats; thus, early death did not occur in kittens that had been inoculated with either FECV UCD, FECV 79-1683, or FIPV UCD-2 prior to a lethal challenge with FIPV 79-1146 
(Pedersen et al., 1984; Pedersen and Floyd, 1985; Fiscus et al., 1987). Of the two kittens vaccinated with FIPV UCD-4 and challenged with a lethal dose of FIPV 79-1146, only one developed enhanced FIP (Pedersen and Floyd, 1985; Pedersen, 1987b). Similarly, of four kittens immunized with FIPV UCD-4, only two died of accelerated FIP after a challenge infection with FIPV UCD-1; one kitten died after the normal, protracted course of the disease, and the other one survived. The combined data indicate that a particular virus-antibody combination is required for the development of $\mathrm{ADE}$ and early death syndrome.

The mechanism of ADE in FIPV remains to be elucidated. An important question that needs to be addressed is whether the dedicated cell surface receptor of FIPV is involved. Scott and co-workers have argued that the enhanced infection occurs via a very efficient form of Fc $\gamma \mathrm{R}$-mediated endocytosis that is independent from the FIPV receptor (Corapi et al., 1992; Olsen et al., 1992). This hypothesis is based upon (1) the "sheer magnitude" of the increase in the number of infected cells due to ADE, (2) the observation that the macrophagelike murine IC-21 cells could be infected with FIPV only in the presence of an enhancing MAb (Corapi et al., 1992), and (3) the as yet unconfirmed claim that ADE can be blocked by lysosomotropic amines (Stoddart, 1989). In this model, the nucleocapsid would be released into the cytoplasm by fusion of the viral envelope and the endosomal membrane (illustrated in Fig. 4B).

The above model is difficult to reconcile with other observations made for coronavirus entry. During normal entry, membrane fusion is mediated by the viral spikes; it occurs readily at neutral $\mathrm{pH}$, but is inhibited at lower $\mathrm{pH}$ values. Therefore, coronaviruses most likely enter the host cell by fusion at the plasma membrane rather than via the endosomal route (see also Chapter 5). Furthermore, heterologously expressed spike proteins induce membrane fusion in a host cell-dependent manner: the spike protein of FIPV only induced cell fusion in cells of feline origin. Similarly, fusion by the $S$ protein of mouse hepatitis virus was restricted to murine cells (de Groot et al., 1989; Vennema et al., 1990a). These data indicate that membrane fusion is a highly specific process, most likely requiring recognition of the cell surface receptor by the viral spikes (Fig. 4A).

Corapi's experiments with the murine IC-21 cells (Corapi et al., 1992) would suggest that during ADE Fc $\gamma$ Rs suffice for viral entry. However, it cannot be excluded that IC-21 cells carry a low affinity receptor for FIPV that is only recognized efficiently when virus-antibody complexes are fixed by the Fc $\gamma$ Rs at the plasma membrane. Support for the existence of FIPV receptors on murine cells stems from studies in which FIPV strains were adapted to murine Sac ${ }^{-}$ cells (de Groot, unpublished results) or propagated in brains of suckling mice (Osterhaus et al., 1978a).

We currently favor a model for ADE in which viral entry is mediated by interaction between the spike and the virus receptor, where the probability of this event is increased due to a more efficient binding of the opsonized virus to the cell surface (explained in Fig. 4C). This mechanism would be similar to that found for human immunodeficiency virus (HIV): ADE of HIV infection requires both the Fc $\gamma \mathrm{R}$ and the HIV cell receptor, CD4 (Takeda et al., 1990; Perno et al., 1990; Zeira et al., 1990; Connor et al., 1991). 

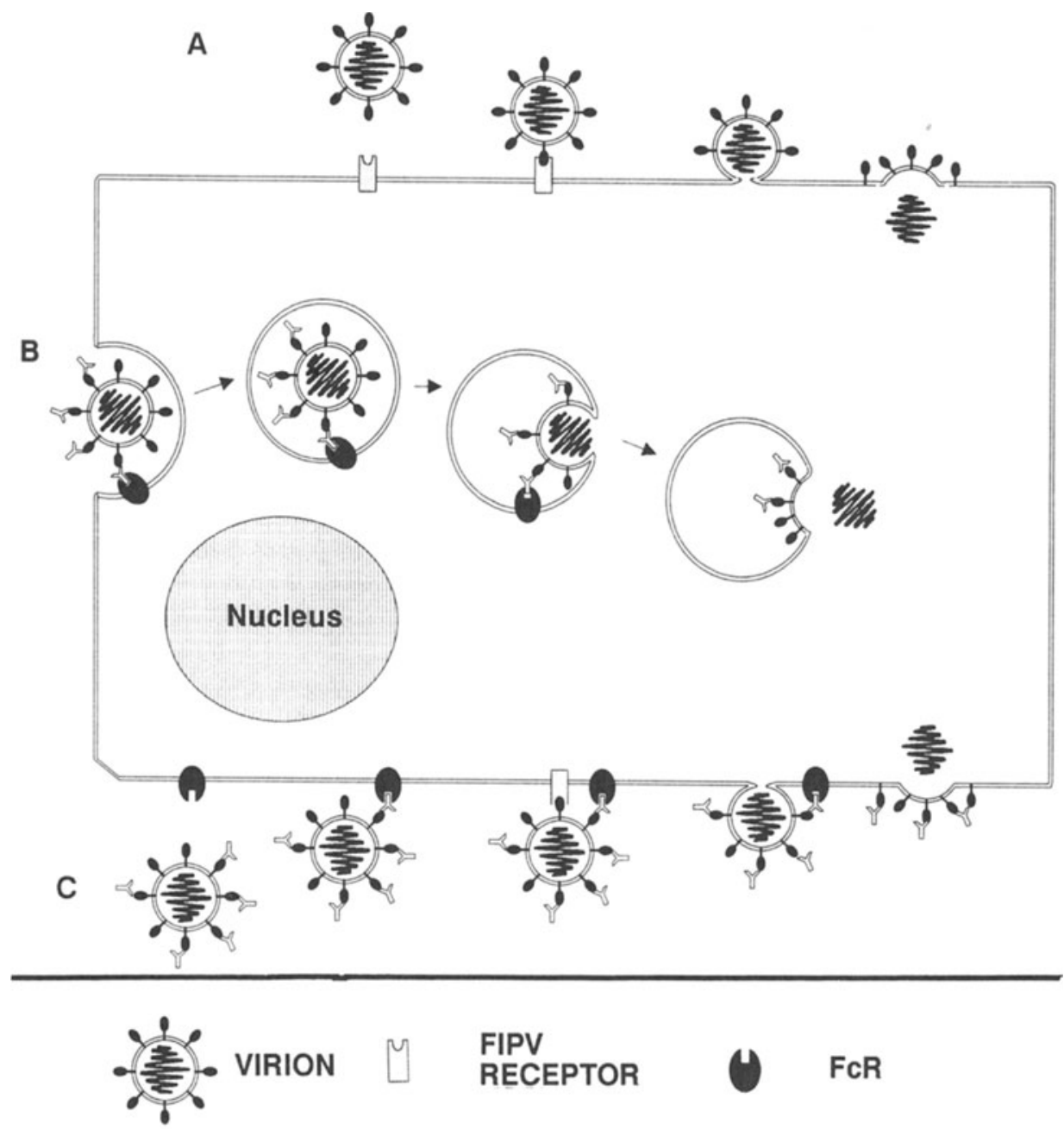

\section{ANTIBODY 紊 NUCLEOCAPSID 9 SPIKE}

FIGURE 4. Models for viral entry during (A) normal infection and (B,C) ADE. (B) Model for ADE, in which entry occurs via the endosomal route. Adsorption and penetration requires only the $\mathrm{Fc}$ receptor. (C) Model for $\mathrm{ADE}$, in which viral entry requires both the Fc receptor and the virus receptor.

Clearly, the receptor for FIPV must be identified before this issue can be resolved. Two closely related viruses, TGEV and HCV 229E, adsorb to and enter their host cell via the aminopeptidase $\mathrm{N}$ (APN) molecule, a membrane-bound metalloprotease (Delmas et al., 1992; Yeager et al., 1992). The tissue distribution of APN coincides with the cell tropism of FIPV; it is present on enterocytes and macrophages (Look et al., 1989). It is thus quite likely that FIPV utilizes APN as a receptor as well. 


\section{IMMUNE-MEDIATED LESIONS IN FIP}

Most authors consider the vascular and perivascular lesions in FIP to be immune-mediated, but there is uncertainty about the actual pathogenic mechanism. At least some vascular injury may be attributed to immune-mediated lysis of infected cells (Weiss and Scott, 1981a): FIPV-infected white blood cells were detected in the lumen, intima and wall of veins and in perivascular locations (Weiss and Scott, 1981a; Weiss et al., 1988). Furthermore, inflammatory mediators such as cytokines (Goitsuka et al., 1988, 1990; Hasegawa and Hasegawa, 1991), leukotrienes, and prostaglandins (Weiss et al., 1988) that are released by infected macrophages could play a pivotal role in the development of the perivascular pyogranulomata. As hypothesized by Weiss et al. (1988), these products could induce vascular permeability changes and provide additional chemotactic stimuli for neutrophils and monocytes. In response to the inflammation, the attracted cells may release additional mediators and cytotoxic substances; the monocytes would also serve as new targets for FIPV. The end result of this would be enhanced local virus production and increased tissue damage.

Other observations point toward an immune complex pathogenesis. Deposition of immune complexes and subsequent complement activation is thought to cause an intense inflammatory response that may extend across blood vessel walls. The resulting vascular damage would permit leakage of fluid into the intercellular space and eventually lead to the accumulation of thoracic and abdominal exudate (Hayashi et al., 1977; Horzinek and Osterhaus, 1979; Jacobse-Geels et al., 1980, 1982; Pedersen and Boyle, 1980; Weiss et al., 1980; Weiss and Scott, 1981a-c). The morphological features of the vascular lesions (necrosis, polymorphonuclear cell infiltration associated with small veins and venules) strongly indicate an Arthus-type reaction (Hayashi et al., 1977; Weiss and Scott, 1981c). The lesions contain focal deposits of virus, IgG, and C3 (Pedersen and Boyle, 1980; Weiss and Scott, 1981b). Moreover, complement depletion and circulating immune complexes were demonstrated in cats with terminal FIP (Pedersen and Boyle, 1980). In a horizontal study of six experimentally infected cats, first clinical signs were accompanied by increased C3 concentrations in the plasma; subsequently, antibody titers and circulating immune complexes (ICX) increased with concomitant decrease of complement concentrations. At the time of death, maximum ICX and minimum C3 concentrations were measured (Jacobse-Geels et al., 1982). Glomerular ICX deposits were found in FIPV-infected cats but not in uninfected controls (Jacobse-Geels et al., 1980).

\section{VACCINE DEVELOPMENT}

The development of vaccines against FIPV is cumbersome and has been frustrated by the occurrence of $\mathrm{ADE}$. Vaccination with heterologous live virus vaccines (TGEV, CCV, HCV 229E) has failed to provide protection (Witte et al., 1977; Toma et al., 1979; Woods and Pedersen, 1979; Barlough et al., 1984, 1985). 
Occasionally, protective immunity can be induced by administering FECV, low virulent FIPV (e.g., FIPV UCD-3), or sublethal amounts of virulent FIPV (Pedersen and Black, 1983; Pedersen et al., 1984; Pedersen and Floyd, 1985; Pedersen, 1987b). However, as quoted from Pedersen and Black (1983, p. 20), the results of immunization with homologous live virus vaccines were "too inconsistent and hazardous to have clinical relevance": while some cats became solidly immune, others developed disease or became sensitized. Also, cats immunized with recombinant vaccinia viruses expressing the spike gene of FIPV 79-1146 (Vennema et al., 1990b) or of FECV 79-1683 (Bhogal, Martinez, Reed, KLepfer, Jones, Pfeiffer, and Miller, in preparation) developed early death syndrome upon an FIPV challenge infection.

A temperature-sensitive strain of FIPV has been shown to stimulate protective immunity in cats. Upon intranasal inoculation into cats, virus replication appeared to be restricted to the upper respiratory tract. The mutant did not differ from the wild-type virus with respect to RNA and protein synthesis, but produced little progeny at the nonpermissive temperature (Christianson et al., 1989; Gerber et al., 1990). There is still controversy over the safety and efficaciousness of this vaccine in that protection may depend on the strain and dose of the challenge virus (Olsen, 1993). Furthermore, even as avirulent and immunizing modified live FIPV strains become available, their widespread use as vaccines is not encouraged in view of the notorious genetic flexibility of coronaviruses. Thus it has been demonstrated that new epidemic strains of avian infectious bronchitis virus have arisen by point mutations in the genomes of attenuated vaccine strains (Kusters et al., 1987). While this may be acceptable in production animals where new vaccine strains can be employed at intervals, the high individual value of a companion animal would plead against the use of live coronavirus vaccines. The possible risks are best illustrated by outbreaks of an unprecedented FIP-like disease in dogs after the widespread use of a modified live CCV vaccine (Martin, 1985).

Designing safe and effective FIP vaccines that avoid immunopathology will probably require a better understanding of the complex interplay between the virus and the host immune system and, perhaps just as important, identification of the viral proteins involved. The molecular cloning of the FIPV genome and the isolation of viral genes provides powerful tools to tackle these problems. Obviously, the $\mathrm{S}$ protein is not the most attractive candidate for vaccine development (Vennema et al., 1990b; Bhogal, Martinez, Reed, Klepfer, Jones, Pfeiffer, and Miller, in preparation). The role of $M$ in immunity against FIPV is still unclear. Upon immunization of eight cats with a vaccinia virus recombinant expressing $M$, three kittens survived, while two other kittens showed protracted survival times compared to the controls (Vennema et al., 1991). Clearly, these findings deserve further scrutiny.

\section{CONCLUDING REMARKS}

Substantial progress has been made in FIP research. Our knowledge of the molecular genetics of FCoVs has increased considerably as has our understand- 
ing of the mechanism of $\mathrm{ADE}$ and early death syndrome. Other areas would require closer examination, for instance, the role of cellular immunity in protection against FIP. As feline cytokine genes are cloned and expressed, new tools become available to modulate the feline immune response and possibly also FIP pathogenesis. Another interesting field is the presumptive FCoV carrier state. It remains to be determined whether FCoVs can cause a true persistent infection, and if so, in which cells and tissues of the host the virus resides and how it manages to escape immunosurveillance. Finally, FCoVs produce a number of proteins that are dispensable for replication in tissue culture cells, most notably $\mathrm{gp} 7 \mathrm{~b}$. What is the function of these proteins during natural infection? Though the last ten years of FIP research have been exciting, the coming years promise to be better still.

ACKNOWLEDGMENTS. The authors thank Arnold Herrewegh, Harry Vennema, Tim Miller, and Wayne Corapi for sharing their unpublished results and Dr. Alfred M. Legendre for critically reading the manuscript. Ad Rijnberk from the Small Animal Clinic of the Utrecht State University drew our attention to the historic publication of Fig. 1, which to our knowledge is the earliest case of FIP documented in veterinary literature.

\section{REFERENCES}

Addie, D. D., and Jarrett, J. O., 1992a, A study of naturally occurring feline coronavirus infections in kittens, Vet. Rec. 130:133.

Addie, D. D., and Jarrett, J. O., 1992b, Feline coronavirus antibodies in cats, Vet. Rec. 131:202.

Barlough, J. E., and Stoddart, C. A., 1986, Feline infectious peritonitis, in: Contemporary Issues in Small Animal Practice 3 (F. W. Scott, ed.), pp. 93-108, Churchill Livingstone, New York.

Barlough, J. E., and Stoddart, C. A., 1990, Feline coronaviral infections, in: Infectious Diseases of the Dog and Cat (C. E. Greene, ed.), pp. 300-311, WB Saunders Co., Philadelphia.

Barlough, J. E., Stoddart, C. A., Sorresso, G. P., Jacobson, R. H., and Scott, F. W., 1984, Experimental inoculation of cats with canine coronavirus and subsequent challenge with feline infectious peritonitis virus, Lab. Anim. Sci. 34:592.

Barlough, J. E., Johnson-Lussenburg, C. M., Stoddart, C. A., Jacobson, R. H., and Scott, F. W., 1985, Experimental inoculation of cats with human coronavirus $229 \mathrm{E}$ and subsequent challenge with feline infectious peritonitis virus, Can. J. Comp. Med. 49:303.

Black, J. W., 1980, Recovery and in vitro cultivation of a coronavirus from laboratory-induced cases of feline infectious peritonitis (FIP), Vet. Med. Small. Anim. Clin. 75:811.

Boyle, J. F., Pedersen, N. C., Evermann, J. F., McKeirnan, A. J., Ott, R. L., and Black, J. W., 1984, Plaque assay, polypeptide composition and immunochemistry of feline infectious peritonitis virus and feline enteric coronavirus isolates, in Molecular Biology and Pathogenesis of Coronaviruses (P. J. M. Rottier, B. A. M. van der Zeijst, W. J. M. Spaan, and M. C. Horzinek, eds.), pp. 133-147, Plenum Press, New York.

Burstin, S. J., Brandriss, M. W., and Schlessinger, J. J., 1983, Effects of immune ascitic fluids and monoclonal antibodies on neutralization and on enhancement of viral growth, $J$. Immunol. 130:2951.

Cavanagh, D., Brian, D. A., Enjuanes, L., Holmes, K. V., Lai, M. M. C., Laude, H., Siddell, S. G., Spaan, W., Taguchi, F., and Talbot, P. J., 1990, Recommendations of the coronavirus study group for the structural proteins, mRNAs and genes of coronaviruses, Virology 176:306.

Chanas, A. C., Gould, E. A., Clegg, J. C., and Varma, M. G. R., 1982, Monoclonal antibodies to Sindbis virus glycoprotein El can neutralize, enhance infectivity, and independently inhibit haemagglutination or haemolysis, J. Gen. Virol. 58:37. 
Christianson, K. K., Ingersoll, J. D., Landon, R. M., Pfeiffer, N. E., and Gerber, J. D., 1989, Characterization of a temperature sensitive feline infectious peritonitis coronavirus, Arch. Virol. 109:185.

Colby, E. D., and Low, R. J., 1970, Feline infectious peritonitis, Vet. Med. Small Anim. Clin. 65:783.

Connor, R. I., Dinces, N. B., Howell, A. L., Romet-Lemonne, J.-L., and Pasquali, J.-L., 1991, Fc receptors for IgG on human monocytes and macrophages are not infectivity receptors for human immunodeficiency virus type 1 (HIV-1): Studies using bispecific antibodies to target HIV-1 to various myeloid cell surface molecules, including the FcyR, Proc. Natl. Acad. Sci. USA 88:9593.

Corapi, W. V., Olsen, C. W., and Scott, F. W., 1992, Monoclonal antibody analysis of neutralization and antibody-dependent enhancement of feline infectious peritonitis, $J$. Virol. 11:6695.

Correa, I., Gebauer, F., Bullido, M. J., Suñé, C., Baay, M. F. D., Zwaagstra, K. A., Posthumus, W. P. A., Lenstra, J. A., and Enjuanes, L., 1990, Localization of antigenic sites of the E2 glycoprotein of transmissible gastroenteritis coronavirus, J. Gen. Virol. 71:271.

Cotter, S. M., Hardy, W. D., and Essex, M., 1975, The association of feline leukemia virus with lymphosarcoma and other disorders, J. Am. Vet. Med. Assoc. 168:448.

de Groot, R. J., Ter Haar, R. J., Horzinek, M. C., and van der Zeijst, B. A. M., 1987a, Intracellular RNAs of the feline infectious peritonitis coronavirus strain 79-1146, J. Gen. Virol. 68:995.

de Groot, R. J., Maduro, J., Lenstra, J. A., Horzinek, M. C., van der Zeijst, B. A. M., and Spaan, W. J. M. $1987 \mathrm{~b}$, cDNA cloning and sequence analysis of the gene encoding the peplomer protein of feline infectious peritonitis virus, J. Gen. Virol. 68:2639.

de Groot, R. J., Luytjes, W., Horzinek, M. C., van der Zeijst, B. A. M., Spaan, W. J. M., and Lenstra, J. A., 1987c, Evidence for a coiled-coil structure in the spike proteins of coronaviruses, J. Mol. Biol. 196:963.

de Groot, R. J., Andeweg, A. C., Horzinek, M. C., and Spaan, W. J. M., 1988, Sequence analysis of the 3 ' end of the feline coronavirus FIPV 79-1146 genome: Comparison with the genome of porcine coronavirus TGEV reveals large insertions, Virology 167:370.

de Groot, R. J., van Leen, R. W., Dalderup, M. J. M., Vennema, H., Horzinek, M. C., and Spaan, W. J. M., 1989, Stably expressed FIPV peplomer protein induces cell fusion and elicits neutralizing antibodies, Virology 171:493.

Delmas, B., Gelfi, J., L’Harridon, R., Vogel, L. K., Sjöström, H., Norén, O., and Laude, H., 1992, Aminopeptidase $\mathrm{N}$ is a major receptor for the enteropathogenic coronavirus TGEV, Nature 357:417.

Evermann, J. F., Baumgartner, L., Ott, R. L., Davis, E. V., and McKeirnan, A. J., 1981, Characterization of a feline infectious peritonitis virus isolate, Vet. Pathol. 18:256.

Feldmann, B. F., and Jortner, B. S., 1964, Clinico-pathology conference, J. Am. Vet. Med. Assoc. 144:1409.

Fiscus, S. A., and Teramoto, Y. A., 1987a, Antigenic comparison of feline coronavirus isolates: Evidence for markedly different peplomer glycoproteins, I. Virol. 61:2607.

Fiscus, S. A., and Teramoto, Y. A., 1987b, Functional differences in the peplomer glycoproteins of feline coronavirus isolates, $J$. Virol. 61:2655.

Fiscus, S. A., Rivoire, B. L., and Teramoto, Y. A., 1987, Humoral immune response of cats to virulent and avirulent feline infectious peritonitis virus isolates, in: Coronaviruses (M. M. C. Lai and S. Stohlman, eds.), pp. 559-568, Plenum Press, New York.

Garwes, D. J., Stewart, F., and Britton, P., 1989, The polypeptide of $M_{r} 14000$ of porcine transmissible gastroenenteritis virus: Gene assignment and intracellular location, J. Gen. Virol. 70:2495.

Gebauer, F., Posthumus, W. P. A., Correa, I., Suñé, C., Smerdou, C., Sánchez, C. M., Lenstra, J. A., Meloen, R. H., and Enjuanes, L., 1991, Residues involved in the antigenic sites of transmissible gastroenteritis coronavirus S glycoprotein, Virology 183:225.

Gerber, J. D., Ingersoll, J. D., Gast, A. M., Christianson, K. K., Selzer, N. L., Landon, R. M., Pfeiffer, N. E., Sharpee, R. L., and Beckenhauer, W. H., 1990, Protection against feline infectious peritonitis by intranasal inoculation of a temperature-sensitive FIPV vaccine, Vaccine 8:536.

Godet, M., L'Haridon, R., Vautherot, J.-F., and Laude, H., 1992, TGEV coronavirus ORF4 encodes a membrane protein that is incorporated into virions, Virology 188:666.

Goitsuka, R., Onda, C., Hirota, Y., Hasegawa, A., and Tomoda, I., 1988, Feline interleukin 1 production induced by feline infectious peritonitis, Ipn. J. Vet. Sci. 50:209. 
Goitsuka, R., Ohashi, T., Ono, K., Yasukawa, K., Koishibara, Y., Fukui, H., Oshugi, Y., and Hasegawa, A., 1990, IL-6 activity in feline infectious peritonitis, J. Immunol. 144:2599.

Gollins, S. W., and Porterfield, J. S., 1984, Flavivirus infection enhancement in macrophages: Radioactive and biological studies on the effect of antibody on viral fate, J. Gen. Virol. 65:1261.

Gollins, S. W., and Porterfield, J. S., 1985, Flavivirus infection enhancement in macrophages: An electron microscopic study of viral cellular entry, J. Gen. Virol. 66:1969.

Gooding, L. R., 1992, Virus proteins that counteract host immune defenses, Cell 71:5.

Halstead, S. B., 1988, Pathogenesis of Dengue: Challenges to molecular biology, Science 239:476.

Halstead, S. B., and O'Rourke, E. J., 1977, Dengue viruses and mononuclear phagocytes. I. Infection enhancement by non-neutralizing antibody, J. Exp. Med. 146:201.

Hardy, W. D., and Hurvitz, A. I., 1971, Feline infectious peritonitis: Experimental studies, J. Am. Vet. Med. Assoc. 158:994.

Hasegawa, T., and Hasegawa, A., 1991, Interleukin 1 alpha mRNA-expressing cells on the local inflammatory response in feline infectious peritonitis, $J$. Vet. Med. Sci. 53:995.

Hayashi, T., Goto, N., Takahashi, R., and Fujiwara, K., 1977, Systemic vascular lesions in feline infectious peritonitis, Ipn. J. Vet. Sci. 39:365.

Hayashi, T., Yanai, T., Tsurudome, M., Nakayama, H., Watabe, Y., and Fujiwara, K., 1981, Serodiagnosis for feline infectious peritonitis by immunofluorescence using infected suckling mouse brain sections, Jap. J. Vet. Sci. 43:669.

Herrewegh, A. A. P. M., De Groot, R. J., Cepica, A., Egberink, H. F., Horzinek, M. C., and Rottier, P. J. M., 1995, Detection of feline cornavirus RNA in feces, tissues, and body fluids of naturally infected cats by reverse transcriptase PCR. J. Clin. Microbiol. 33(3), in press.

Hohdatsu, T., Okada, S., and Koyama, H., 1991a, Characterization of monoclonal antibodies against feline infectious peritonitis virus type II and antigenic relationship between feline, porcine, and canine coronaviruses, Arch. Virol. 117:85.

Hohdatsu, T., Sasamoto, T., Okada, S., and Koyama, H., 1991b, Antigenic analysis of feline coronaviruses with monoclonal antibodies (MAbs): Preparation of MAbs which discriminate between FIPV strain 79-1146 and FECV strain 79-1683, Vet. Microbiol. 28:13.

Hohdatsu, T., Nakamura, Y., Yamada, H., and Koyama, H., 1991c, A study on the mechanism of antibody-dependent enhancement of feline infectious peritonitis virus infection in feline macrophages by monoclonal antibodies, Arch. Virol. 120:207.

Hohdatsu, T., Okada, S., Ishizuka, Y., Yamada, H., and Koyama, H., 1992, The prevalence of types I and II feline coronavirus infections in cats, $J$. Vet. Med. Sci. 54:557.

Holzworth, J., 1963, Some important disorders of cats, Cornell Vet. 53:157.

Horsburgh, B. C., Brierley, I., and Brown, T. D. K., 1992, Analysis of a $9.6 \mathrm{~kb}$ sequence from the 3 ' end of canine coronavirus genomic RNA, J. Gen. Virol. 73:2849.

Horzinek, M. C., and Osterhaus, A. D. M. E., 1979, Feline infectious peritonitis: A world-wide serosurvey, Am. J. Vet. Res. 40:1487.

Horzinek, M. C., Osterhaus, A. D. M. E., and Ellens, D. J., 1977, Feline infectious peritonitis, Zbl. Vet. Med. [B] 24:398.

Horzinek, M. C., Lutz, H., and Pedersen, N. C., 1982, Antigenic relationships among homologous structural polypeptides of porcine, feline and canine coronaviruses, Infect. Immun. 37:1148.

Jacobs, L., de Groot, R. J., van der Zeijst, B. A. M., Horzinek, M. C., and Spaan, W. J. M., 1987, The nucleotide sequence of the peplomer gene of porcine transmissible gastroenteritis virus (TGEV): Comparisosn with the sequence of the peplomer protein of feline infectious peritonitis virus (FIPV), Virus Res. 8:363.

Jacobse-Geels, H. E. L., and Horzinek, M. C., 1983, Expression of feline infectious peritonitis coronavirus antigens on the surface of feline macrophage-like cells, J. Gen. Virol. 64:1859.

Jacobse-Geels, H. E. L., Daha, M. R., and Horzinek, M. C., 1980, Isolation and characterization of feline $\mathrm{C} 3$ and evidence for the immune complex pathogenesis of feline infectious peritonitis virus, I. Immunol. 125:1606.

Jacobse-Geels, H. E. L., Daha, M. R., and Horzinek, M. C., 1982, Antibody, immune complexes and complement activity fluctuations in experimental feline infectious peritonitis, Am. J. Vet. Res. 43:666.

Jakob, H., 1914, Therapeutische, kasuistische und statistische Mitteilungen aus der Klinik für kleine Haustiere an der Reichstierarzneischule in Utrecht (Holland). Jahrgang 1912/13, Zschr. Tiermed. 18:193. 
Kapke, P. A., and Brian, D. A., 1986, Sequence analysis of the porcine transmissible gastroenteritis coronavirus nucleocapsid protein gene, Virology 151:41.

Kusters, J. G., Niesters, H. G. M., Bleumink-Pluym, N. M. C., Davelaar, F. G., Horzinek, M. C., and van der Zeijst, B. A. M., 1987, Molecular epidemiology of infectious bronchitis virus in the Netherlands, J. Gen. Virol. 68:343.

Loeffler, D. G., Ott, R. L., Evermann, J. F., and Alexander, J. E., 1978, The incidence of naturally occurring antibodies against feline infectious peritonitis in selected cat populations, Feline Pract. 8:43.

Look, A. T., Ashmun, R. A., Shapiro, L. H., and Peiper, S. C., 1989, Human myeloid plasma membrane glycoprotein CD13 (gp150) is identical to aminopeptidase N, J. Clin. Invest. 83:1299.

Martin, M. L., 1985, Canine coronavirus enteritis and a recent outbreak following modified live virus vaccination, Compend. Cont. Educ. Pract. Vet. 7:1013.

McArdle, F., Bennet, M., Gaskell, R. M., Tennant, B., Kelly, D. F., and Gaskell, C. J., 1992, Induction and enhancement of feline infectious peritonitis by canine coronavirus, Am. J. Vet. Res. 53:1500.

McKeirnan, A. J., Evermann, J. F., Hargis, A., Miller, L. M., and Ott, R. L., 1981, Isolation of feline coronaviruses from two cats with diverse disease manifestations, Feline Pract. 11:16.

Montali, R. J., and Strandberg, J. D., 1972, Extraperitoneal lesions in feline infectious peritonitis, Vet. Pathol. 9:109.

Motokawa, K., Hohdatsu, T., Aizawa, C., Koyama, H., and Hashimoto, H., 1995, Molecular cloning and sequence determination of the peplomer protein gene of feline infectious peritonitis virus type I, Arch. Virol. 140:469.

O'Brien, S. J., Roelke, M. E., Marker, L., Newman, A., Winkler, C. A., Meltzer, D., Colly, L., Evermann, J. F., Bush, M., and Wildt, D. E., 1985, Genetic basis for species vulnerability in the Cheetah, Science 227:1428.

Olsen, C. W., 1993, A review of feline infectious peritonitis virus: Molecular biology, immunopathogenesis, clinical aspects, and vaccination, Vet. Microbiol. 36:1.

Olsen, C. W., and Scott, F., 1993, Evaluation of antibody-dependent enhancement of feline infectious peritonitis virus infectivity using in situ hybridization, Microbial Pathogen. 14:275.

Olsen, C. W., Corapi, W. V., Ngichabe, C. K., Baines, J. D., and Scott, F. W., 1992, Monoclonal antibodies to the spike protein of feline infectious peritonitis virus mediate antibodydependent enhancement of infection of feline macrophages, J. Virol. 66:956.

Olsen, C. W., Corapi, W. V., Jacobson, R. H., Simkins, R. A., Saif, L. J., and Scott, F. W., 1993, Identification of antigenic sites mediating antibody-dependent enhancement of feline infectious peritonitis virus infectivity, J. Gen. Virol. 74:745.

O'Reilly, K. J., Fishman, L. M., and Hitchcock, L. M., 1979, Feline infectious peritonitis: Isolation of a coronavirus, Vet. Rec. 104:348.

Osterhaus, A. D. M. E., Horzinek, M. C., and Wirahadiredja, R. M. S., 1978a, Feline infectious peritonitis (FIP) virus. II. Propagation in suckling mouse brain, Zbl. Vet. Med. [B] 25:301.

Osterhaus, A. D. M. E., Horzinek, M. C., and Wirahadiredja, R. M. S., 1978b, Feline infectious peritonitis (FIP) virus. IV. Propagation in suckling rat and hamster brain, Zbl. Vet. Med. [B] 25:816.

Pedersen, N. C., 1976a, Morphologic and physical characteristics of feline infectious peritonitis virus and its growth in autochtonous peritoneal cell cultures, Am. J. Vet. Res. 37:567.

Pedersen, N. C., 1976b, Feline infectious peritonitis: Something old, something new, Feline Pract. 6:42.

Pedersen, N. C., 1976c, Serologic studies of naturally occurring feline infectious peritonitis, Am. J. Vet. Res. 37:1449.

Pedersen, N. C., 1983a, Feline infectious peritonitis and feline enteric coronavirus infections, part 1: Feline enteric coronaviruses, Feline Pract. 13(4):13.

Pedersen, N. C., 1983b, Feline infectious peritonitis and feline enteric coronavirus infections, part 2: Feline infectious peritonitis, Feline Pract. 13(5):5.

Pedersen, N. C., 1987a, Feline infectious peritonitis virus, in: Virus Infections of Carnivores (M. C. Horzinek and M. Appel, eds.), pp. 267-286, Elsevier Science Publishers, Amsterdam.

Pedersen, N. C., 1987b, Virologic and immunologic aspects of feline infectious peritonitis virus 
infection, in: Coronaviruses (M. M. C. Lai and S. Stohlman, eds.), pp. 529-550, Plenum Press, New York.

Pedersen, N. C., and Black, J. W., 1983, Attempted immunization of cats against feline infectious peritonitis, using avirulent live virus or sublethal amounts of virulent virus, Am. J. Vet. Res. 44:229.

Pedersen, N. C., and Boyle, J. F., 1980, Immunologic phenomena in the effusive form of feline infectious peritonitis, Am. J. Vet. Res. 41:868.

Pedersen, N. C., and Floyd, K., 1985, Experimental studies with three new strains of feline infectious peritonitis virus: FIPV-UVD2, FIPV-UCD3, and FIPV-UCD4, Compend. Contin. Educ. Pract. Vet. 7:1001.

Pedersen, N. C., Ward, J. M., and Mengeling, W. L., 1978, Antigenic relationship of the feline infectious peritonitis virus to coronaviruses of other species, Arch. Virol. 58:45.

Pedersen, N. C., Boyle, J. F., and Floyd, K., 1981a, Infection studies in kittens utilizing feline infectious peritonitis virus propagated in cell culture, Am. J. Vet. Res. 42:363.

Pedersen, N. C., Boyle, J. F., Floyd, K., Fudge, A., and Barker, J., 1981b, An enteric coronavirus infection of cats and its relationship to feline infectious peritonitis, Am. J. Vet. Res. 42:368.

Pedersen, N. C., Black, J. W., Boyle, J. F., Evermann, J. F., McKeirnan, A. J., and Ott, R. L., 1983, Pathogenic differences between various feline coronavirus isolates, in: Molecular Biology and Pathogenisis of Coronaviruses (P. J. M. Rottier, B. A. M. van der Zeijst, W. J. M. Spaan, and M. C. Horzinek, eds.), pp. 365-380, Plenum Press, New York.

Pedersen, N. C., Evermann, J. F., Alison, J., McKeirnan, A. J., and Ott, R. L., 1984, Pathogenicity studies of feline coronavirus isolates 79-1146 and 79-1683, Am. J. Vet. Res. 45:2580.

Peiris, J. S. M., and Porterfield, J. S., 1979, Antibody-mediated enhancement of flavivirus replication in macrophage-like cell lines, Nature 282:509.

Peiris, J. S. M., Gordon, S., Unkeless, J. C., and Porterfield, J. S., 1981, Monoclonal anti-Fc receptor IgG blocks antibody enhancement of viral replication in macrophages, Nature 289:189.

Perno, C.-F., Baseler, M. W., Broder, S., and Yarchoan, R., 1990, Infection of monocytes by human immunodeficiency virus type 1 blocked by inhibitors of CD4-gp120 binding, even in the presence of enhancing antibodies, J. Exp. Med. 171:1043.

Poelma, F. G., Peters, J. C., Mieog, W. H. M., and Zwart, P., 1971, Infektiöse Peritonitis bei Karakal (Felis caracal) und Nordluchs (Felis lynx lynx), in: Erkrankungen der Zootiere, pp. 249-283, 13th International Symposium, Helsinki.

Porterfield, J. S., 1986, Antibody-dependent enhancement of viral infectivity, Adv. Virus Res. 31:335.

Reynolds, D. J., Garwes, D. J., and Gaskell, C. J., 1977, Detection of transmissible gastroenteritis virus neutralizing antibody in cats, Arch. Virol. 55:77.

Scott, F. W., 1987, Immunization against feline cornaviruses, in: Cornaviruses (M. M. C. Lai and S. Stohlman, eds.), pp. 569-576, Plenum Press, New York.

Sneath, P. H. A., and Sokal, R. R., 1973, in: Numeral Taxonomy, pp. 230-234, W. H. Freeman and Company, San Francisco.

Sparkes, A. H., Gruffydd-Jones, T. J., and Harbour, D. A., 1991, Feline infectious peritonitis: A review of clinical pathological changes in 65 cases and a critical assessment of their diagnostic value, Vet. Rec. 129:209.

Sparkes, A. H., Gruffydd-Jones, T. J., Howard, P. E., and Harbour, D. A., 1992, Coronavirus serology in healthy pedigree cats, Vet. Rec. 131:35.

Stoddart, C. A., 1989, PhD thesis, Cornell University, Ithaca, NY.

Stoddart, C. A., and Scott, F. W., 1988, Isolation and identification of feline peritonteal macrophages for in vitro studies of coronavirus-macrophage interactions, I. Leukocyte Biol. 44:319.

Stoddart, C. A., and Scott, F. W., 1989, Intrinsic resistance of feline peritoneal macrophages to coronavirus infection correlates with in vivo virulence, $J$. Virol. 63:436.

Stoddart, M. E., Gaskell, R. M., Harbour, D. A., and Gaskell, C. J., 1988a, Virus shedding and immune responses in cats inoculated with cell culture-adapted feline infectious peritonitis virus, Vet. Microbiol. 16:145.

Stoddart, M. E., Gaskell, R. M., Harbour, D. A., and Pearson, G. R., 1988b, The sites of early viral replication in feline infectious peritonitis, Vet. Microbiol. 18:259. 
Takeda, A., Tuazon, C. U., and Ennis, F. A., 1988, Antibody-enhanced infection by HIV-1 via Fc receptor-mediated entry, Science 242:580.

Takeda, A., Sweet, R. W., and Ennis, F. A., 1990, Two receptors are required for antibody-dependent enhancement of human immunodeficiency virus type 1 infection: CD4 and FcyR, J. Virol. 64:5605.

Toma, B., Duret, C., Chappuis, G., and Pellerin, B., 1979, Échec de l'immunisation contre la péritonite infectieuse féline par injection de virus de la gastro-entérite transmissible du porc, Rec. Med. Vet. 155:799.

Tuch, K., Witte, K. H., and Wüller, H., 1974, Feststellung der felinen infektiösen Peritonitis (FIP) bei Hauskatzen und Leoparden in Deutschland, Zbl. Vet. Med. [B] 21:426.

Tung, F. Y., Abraham, S., Sethna, M., Hung, S.-L., Sethna, P., Hogue, B. G., and Brian, D. A., 1992, The $9-\mathrm{kDa}$ hydrophobic protein encoded at the $3^{\prime}$ end of the porcine transmissible gastroenteritis coronavirus genome is membrane-associated, Virology 186:676.

Vennema, H., Heijnen, L., Zijderveld, A., Horzinek, M. C., and Spaan, W. J. M., 1990a, Intracellular transport of recombinant coronavirus spike proteins: Implications for virus assembly, $J$. Virol. 64:339.

Vennema, H., de Groot, R. J., Harbour, D., Daalderup, M., Gruffydd-Jones, T., Horzinek, M. C., and Spaan, W. J. M., 1990b, Early death after feline infectious peritonitis virus challenge due to recombinant vaccinia virus immunization, J. Virol. 64:1407.

Vennema, H., de Groot, R. J., Harbour, D. A., Horzinek, M. C., and Spaan, W. J. M., 1991, Primary structure of the membrane and nucleocapsid protein genes of feline infectious peritonitis virus and immunogenicity of recombinant vaccinia viruses in kittens, Virology 181:327.

Vennema, H., Heijen, L., Rottier, P. J. M., Horzinek, M. C., and Spaan, W. J. M., 1992a, A novel glycoprotein of feline infectious peritonitis coronavirus contains a KDEL-like endoplasmic reticulum retention signal, J. Virol. 66:4951.

Vennema, H., Rossen, J. W., Wesseling, J. Horzinek, M. C., and Rottier, P. J. M., 1992b, Genomic organization and expression of the $3^{\prime}$ end of the canine and feline enteric coronaviruses, Virology 191:134.

Vennema, H., Poland, A., Floyd Hawkins, K., and Pedersen, N. C., 1995, A comparison of the genomes of FECVs and FIPVs and what they tell us about the relationships between feline coronaviruses and their evolution, Feline Practice, in press.

Ward, J. M., 1970, Morphogenesis of a virus in cats with experimental feline infectious peritonitis, Virology 41:191.

Ward, J. M., Munn, R. J., Gribble, D. H., and Dungworth, D. L., 1968, An observation of FIP, Vet. Res. 83:416.

Watt, N. J., MacIntyre, N. J., and McOrist, S., 1993, An extended outbreak of infectious peritonitis in a closed colony of European wildcats (Felis silvestris), J. Comp. Pathol. 108:73.

Weiss, R. C., and Scott, F. W., 1981a, Pathogenesis of feline infectious peritonitis: Nature and development of viremia, Am. J. Vet. Res. 42:382.

Weiss, R. C., and Scott, F. W., 1981b, Antibody-mediated enhancement of disease in feline infectious peritonitis: Comparisons with Dengue hemorrhagic fever, Comp. Immun. Microbiol. Infect. Dis. 4:175.

Weiss, R. C., and Scott, F. W., 1981c, Pathogenesis of feline infectious peritonitis: Pathologic changes and immunofluorescence, Am. J. Vet. Res. 42:2036.

Weiss, R. C., Dodds, W. J., and Scott, F. W., 1980, Dissiminated intravascular coagulation in experimentally induced feline infectious peritonitis, Am. J. Vet. Res. 41:663.

Weiss, R. C., Vaughn, D. M., and Cox, N. R., 1988, Increased plasma levels of leukotriene B4 and prostaglandin $\mathrm{E} 2$ in cats experimentally inoculated with feline infectious peritonitis virus, Vet. Res. Commun. 12:313.

Witte, K. H., Tuch, K., Dubenkropp, H., and Walther, C., 1977, Untersuchungen über die Antigenverwandtschaft der Viren der Felinen infektiösen Peritonitis und der transmissibelen Gastroenteritis des Schweines, Berl. Münch. Tierärztl. Wschr. 90:396.

Wolfe, L. G., and Griesemer, R. A., 1966, Feline infectious peritonitis, Pathol. Vet. 3:255.

Wolfe, L. G., and Griesemer, R. A., 1971, Feline infectious peritonitis: Review of gross and histopathologic lesions, J. Am. Vet. Med. Assoc. 158:987. 
Woods, R. D., and Pedersen, N. C., 1979, Cross-protection studies between feline infectious peritonitis and porcine transmissible gastroenteritis viruses, Vet. Microbiol. 4:11.

Woods, R. D., Cheville, N. F., and Gallagher, J. E., 1981, Lesions in the small intestine of newborn pigs inoculated with porcine, feline and canine coronaviruses, Am. J. Vet. Res. 42:1163.

Yeager, C. L., Ashmun, R. A., Williams, R. K., Cardellichio, C. B., Shapiro, L. H., Look, A. T., and Holmes, K. V., 1992, Human aminopeptidase $\mathrm{N}$ is a receptor for human coronavirus $229 \mathrm{E}$, Nature 357:420.

Zeira, M., Byrn, R. A., and Groopman, J. E., 1990, Inhibition of serum-enhanced HIV-1 infection of U937 monocytoid cells by recombinant soluble CD4 and anti-CD4 monoclonal antibody, AIDS. Res. Hum. Retroviruses 6:629.

Zhou, Y., Ederveen, J., Egberink, H., Pensaert, M., and Horzinek, M. C., 1988, Porcine epidemic diarrhea virus (CV 777) and feline infectious peritonitis virus (FIPV) are antigenically related, Arch. Virol. 102:63.

Zook, B. C., King, N. W., Robinson, R. L., and McCombs, H. L., 1968, Ultrastructural evidence for the viral etiology of feline infectious peritonitis, Pathol. Vet. 5:91. 